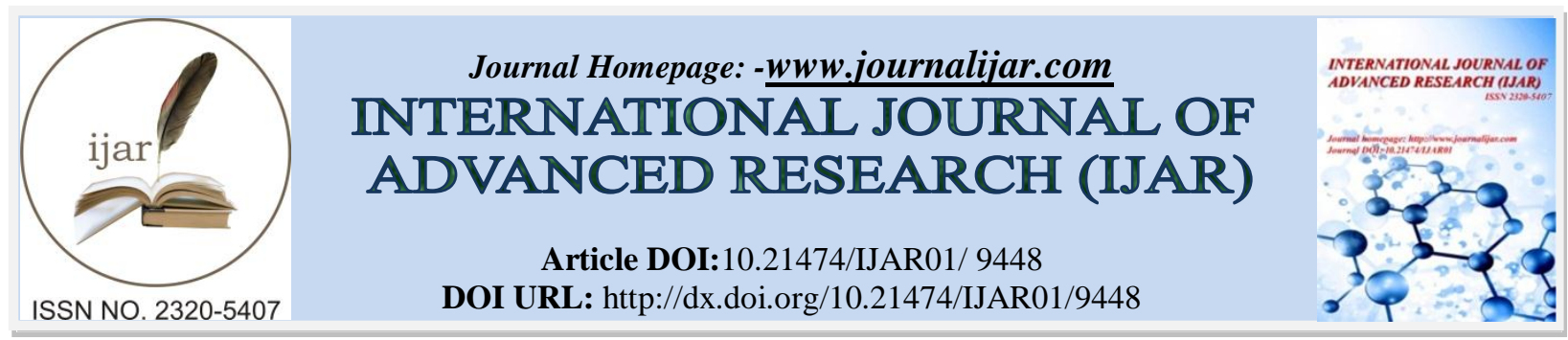

RESEARCH ARTICLE

\title{
INDIRECT ORGANOGENESIS IN SOLID AND LIQUID MEDIUMS FROM VITROPLANTS OF AGAVE TITANOTA.
}

López-Isabel B ${ }^{1}$, Martínez-Hernández Ma. de $\mathbf{J}^{\mathbf{1}}$, Nader-García B. $\mathrm{L}^{\mathbf{2}}$ and Adame- García $\mathrm{J}^{\mathbf{3}}$.

1. Facultad de Ciencias Agrícolas, Universidad Veracruzana Circuito Gonzalo Aguirre Beltrán s/n Zona Universitaria C.P. 91090 Xalapa, Veracruz, México.

2. Facultad de Biología, Universidad Veracruzana, Circuito Gonzalo Aguirre Beltrán s/n Zona Universitaria C.P. 91090 Xalapa, Veracruz, México.

3. Tecnológico Nacional de México-Instituto Tecnológico de Úrsulo Galván, km 4.5 Carr. Cardel-Chachalacas, CP. 91667. Úrsulo Galván, Veracruz, Mexico.

\section{Manuscript Info}

Manuscript History

Received: 24 May 2019

Final Accepted: 26 June 2019

Published: July 2019

\section{Key words:-}

In vitro, culture, Agavaceae, embryogenic callus.

\section{Abstract}

In vitro cultivation is a useful technique for study, improvement and conservation of agaves. It was used as explants pieces of leaves and roots in MS solid and liquid mediums respectively, supplemented with Naphtaleneacetic Acid (NAA by its abbreviations in English) Benzylaminopurine (BAP by its abbreviations in English) and Dichlorophenoxyacetic Acid (2,4-D by its abbreviations in English) It was used concentrations of $0.0,0.5,1.0$ and $2.0 \mathrm{mgl}-1$ to induce shoot formation. It was reported the development of callus within one month and half on solid cultivation, shoot formations were presented using 2.0 mgl-1 BAP and $0.5 \mathrm{mgl}-1$ of NAA having $60 \pm 1$ shoots each container with hydration aspect, meanwhile in the combination $1.5 \mathrm{mgl}-1$ of BAP with 0.5 mgl-1 of NAA a lower number of shoots was reached, but they were healthier. The formation of shoots in liquid medium was presented within a month of cultivation, obtaining $6.6 \pm 1$ shoots by healthy explants, even in the control treatment. Embryogenic callus was generated using BAP and 2,4-D.

Copy Right, IJAR, 2019,. All rights reserved.

\section{Introduction:-}

During the last few years, vegetable tissue cultivation has emerged as a powerful tool for the effective propagation of agaves through organogenesis and embryogenesis of several explants; such as seeds, rhizomes, stem, bulbs, leaves, stolons, shoots and cotyledons (Zhang et al., 2013) thus, this technique allows vegetative propagation of thousands of plants genetically similar to mother plant (Abreu et al., 2007) within a short time; moreover, healthy and pathogen free plants are obtained. (Morales-Gonzalez and Nuñez-Palenius, 2015) in reduced spaces under controlled conditions (Castellanos-Hernandez et al., 2006).

In vitro culture of vegetable cells and tissues can be used to rescue and preserve endangered species, for massive multiplication of superior genotypes, in this way, to obtain huge clone populations coming from selected plants (Miguel-Luna et al., 2013) within a short time, furthermore, it represents an alternative to recover species which

Corresponding Author:-Martínez Hernández Ma. De J.

Address:-Facultad de Ciencias Agrícolas, Universidad Veracruzana Circuito Gonzalo Aguirre Beltrán s/n Zona Universitaria C.P. 91090 Xalapa, Veracruz, México. 
have significantly diminished their populations due to excessive exploitation without a handle plan (Enriquez-del Valle et al., 2013).

Direct or indirect organogenesis has been reported for several species, like Agave arizonica (Powers and Backhaus, 1989), A. atrovirens and A. fourcroydes (Madrigal-Lugo et al., 1989; Robert et al., 1987), A. cantala and A. sisalana (Binh et al., 1990), Agave sp. (Groenewald et al., 1977) and A. tequilana (Castro-Concha et al., 1990; Rodriguez-Garay et al., 1996) among others, as well as somatic embryogenesis has been reported for several endangered ornamental species (Santacruz-Ruvalcaba et al., 1999).

The usage of micropropagation in vitro has several advantages. Such as the obtention of populations with elite characteristics, tolerance to stress, pathogen free and stable genetic background. This technique can also provide material for the improvement of cultures using molecular tools (Puente-Garza et al., 2015), it represents a great advantage, since the genetic improvement of agaves by conventional techniques is complex because of the long time required (10 to 20 years) to generate seeds, characteristic period of these plants, (Arzate-Fernandez and MejiaFranco, 2011).

On the other hand, somatic embryogenesis is considered as a powerful tool for regeneration and genetic improvement of plants, which can be induced in a direct way over the explant or indirectly from the callus. This morphogenetic process is favored by transferring the explants from one culture medium supplemented with high concentration of auxins to another one free of these growth regulators (Arzate-Fernández and Mejia-Franco, 2011); this technique produces somatic embryos and can be used to produce synthetic seeds (Bordallo et al., 2004).

The present research has as an objective to set an efficient method of massive propagation that can help to avoid the decrease of wild populations of Titanota Agave Gentry, species under special protection. Through micropropagation indirect organogenesis via starting from leaf and root segments in liquid and solid medium respectively. As well as to find optimal concentrations of Naphtaleneacetic acid (NAA), Dichlorophenoxyacetic Acid (2,4-D) and Benzylaminopurine (BAP) for shoots formation.

\section{Methods and Materials:- Obtention of explant}

The explants were obtained from germinated seedlings in vitro of four months old, two types of explant were used: leaves and roots.

\section{Preparation of culture medium}

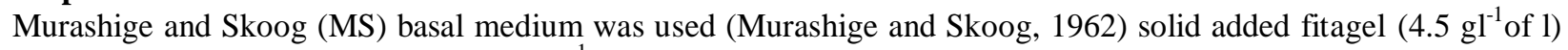
and broth, both supplemented with $30 \mathrm{gl}^{-1}$ of saccharose; $\mathrm{pH}$ was adjusted to $5.70 \pm 0.1$. To the medium, growth regulators were added, for which a hormonal swept was carried out to stimulate shoot formations as it is shown in (Table 1). Erlenmeyer matrasses which contained $50 \mathrm{ml}$ of liquid medium and glass bottles of $120 \mathrm{ml}$ of capacity containing $20 \mathrm{ml}$ of solid medium; they were sterilized to $120 \mathrm{~kg} / \mathrm{cm}^{2}$ pressure and a temperature of $120{ }^{\circ} \mathrm{C}$ during 18 minutes.

Table 1:-Hormonal swept for shoot generation

\begin{tabular}{|c|c|c|c|c|}
\hline \multicolumn{5}{|c|}{ Solid Medium } \\
\hline TREAT & MS & NAA & BAP & $2,4-$ D \\
\hline A & + & - & - & - \\
\hline B & + & 0.5 & 1.0 & - \\
\hline C & + & 0.5 & 1.5 & - \\
\hline D & + & 0.5 & 2.0 & - \\
\hline E & + & 0.5 & 0.5 & - \\
\hline F & + & 1.0 & 0.5 & - \\
\hline G & + & 1.5 & 0.5 & - \\
\hline H & + & 2.0 & 0.5 & 0.5 \\
\hline I & + & - & 0.5 & 1.0 \\
\hline J & + & - & & - \\
\hline
\end{tabular}




\begin{tabular}{|c|c|c|c|c|}
\hline K & + & - & 0.5 & 1.5 \\
\hline $\mathrm{L}$ & + & - & 0.5 & 2.0 \\
\hline $\mathrm{M}$ & + & - & 1.0 & 0.5 \\
\hline $\mathrm{N}$ & + & - & 1.5 & 0.5 \\
\hline $\mathrm{O}$ & + & - & 2.0 & 0.5 \\
\hline \multicolumn{5}{|c|}{ Liquid Medium } \\
\hline \multicolumn{2}{|c|}{ TREAT } & MS & NAA & BAP \\
\hline \multicolumn{2}{|c|}{$\mathrm{A}$} & + & - & - \\
\hline \multicolumn{2}{|c|}{$\mathrm{B}$} & + & 0.5 & 0.5 \\
\hline \multicolumn{2}{|c|}{$\mathrm{C}$} & + & 0.5 & 1.0 \\
\hline \multicolumn{2}{|c|}{$\mathrm{D}$} & + & 0.5 & 1.5 \\
\hline \multicolumn{2}{|c|}{$\mathrm{E}$} & + & 0.5 & 2.0 \\
\hline
\end{tabular}

\section{Planting the explant}

Seeding was carried out in uninfected conditions, cuts in seedlings were done mainly to split aerial part of root; later, each leaf was transversally cut to generate from two to three explants. As for the root, it was totally used. Two fragments of leaf were deposited in a crossed way by bottle and a root by matrass. The cultures in liquid medium were set in an orbital shaker at $100 \mathrm{rpm}$, inside the growth chamber with white light (photoperiod 24h light) at a temperature of $27 \pm 2{ }^{\circ} \mathrm{C}$ and a relative humidity between $80-90 \%$.

\section{Statistical Analysis}

The response of all treatments was evaluated weekly during two months. From the combination of factors 20 treatments were obtained, in a design completely random with 10 repetitions each one and having from one to two explants every experimental unit (bottle or matrass). The response variables studied were the percentage of explants that produced outbreaks and the number of outbreaks produced per treatment.

Results were evaluated with an analysis of variance (ANOVA by its abbreviations in English) and a multiple comparison of Tukey measures $(\mathrm{P} \leq 0.05)$, with the Statistical Analysis Software (SAS by its abbreviations in English version 9.1).

\section{Results and Discussion:-}

The obtained explants for this procedure came from a previous culture treatment in vitro that guaranteed axenic material. Growth regulators in distinct sweeps showed a response to stimulation of direct as indirect organogenesis (Table 2). Leaves produced indirect organogenesis due to it was obtained first callus, then it was spread in shoots of agave. It occurred in MS solid medium supplemented with NAA and BAP, in two months 60 shoots were produced by each flask in a concentration of $0.5 \mathrm{mgl}^{-1}$ NAA plus $1.5 \mathrm{mgl}^{-1}$ BAP (Fig. 1).

Table 2:-Organogenesis Analysis

\begin{tabular}{|c|c|c|c|c|c|c|}
\hline \multirow{4}{*}{ Medium } & Response & Callus & Shoots & Root & Oxidation & Contamination \\
\cline { 2 - 7 } & Treatment & \multicolumn{7}{|c|}{} \\
\hline \multirow{5}{*}{ MS Solid } & A & ++ & - & - & +++ & - \\
\cline { 2 - 7 } & B & ++ & ++ & + & ++ & - \\
\cline { 2 - 7 } & C & +++ & + & + & +++ & - \\
\cline { 2 - 7 } & D & ++ & +++ & - & - & - \\
\cline { 2 - 7 } & E & +++ & ++ & - & - & - \\
\cline { 2 - 7 } & F & +++ & - & ++ & +++ & - \\
\cline { 2 - 7 } & H & +++ & + & ++ & - & - \\
\cline { 2 - 7 } & I & +++ & + & - & - & - \\
\hline
\end{tabular}




\begin{tabular}{|c|c|c|c|c|c|c|}
\hline \multirow{4}{*}{} & $\mathrm{K}$ & + & - & - & +++ & - \\
\cline { 2 - 7 } & $\mathrm{L}$ & +++ & - & - & + & - \\
\cline { 2 - 7 } & $\mathrm{M}$ & ++ & - & - & + & - \\
\cline { 2 - 7 } & $\mathrm{N}$ & + & - & - & - & - \\
\hline \multirow{4}{*}{ MS Liquid } & $\mathrm{O}$ & + & - & - & ++ & - \\
\cline { 2 - 7 } & $\mathrm{a}$ & +++ & - & - & - & - \\
\cline { 2 - 7 } & $\mathrm{b}$ & +++ & - & - & - & - \\
\cline { 2 - 7 } & $\mathrm{c}$ & + & - & - & - \\
\cline { 2 - 7 } \\
\cline { 2 - 7 } & $\mathrm{d}$ & ++ & - & - & - \\
\hline
\end{tabular}

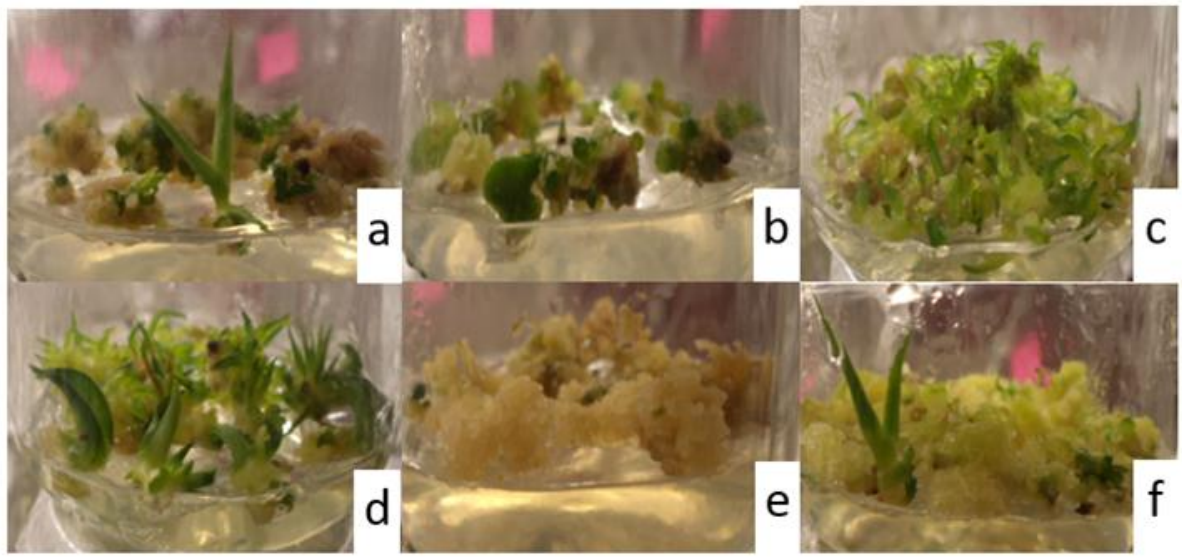

Fig 1:-Formation of callus and shoots. a) 0.5 NAA + 0.5 BAP, b) $0.5 \mathrm{NAA}+1.0 \mathrm{BAP}$, c) $0.5 \mathrm{NAA}+1.5 \mathrm{BAP}$, d) $0.5 \mathrm{NAA}+2.0 \mathrm{BAP}, \mathrm{e}) 0.5 \mathrm{BAP}+1.0 \mathrm{NAA}$ and f) $0.5 \mathrm{BAP}+1.5 \mathrm{NAA}\left(\mathrm{mgL}^{-1}\right)$.

In 2012, Angeles-Espino et al., employed axillary buds of A. tequilana Weber and obtained shoots in a period of one month using MS supplemented with $2.5 \mathrm{mgl}^{-1}$ Indole Butyric Acid (IBA) $+4.5 \mathrm{mgl}^{-1}$ Cin. Sanchez-Islas and Portillo during 2014 studied to A. horrida and A. rzedowskiana setting the leaf in Log medium supplemented with saccharose and they obtained the formation of shoots.

Was observed direct organogenesis in MS liquid medium free of growth regulators (Fig. 2), meanwhile liquid medium with growth regulators presented formation of compacted callus, in this case it was not possible to watch shoots. The obtained shoots in liquid when sub-cultured in solid medium did not develop, so that they were kept in liquid medium, at the end of two months they tend to hydrate. Aureoles-Rodríguez et al., in 2008 worked with $A$. inaequidens Koch employing axillary buds and stem in MS with 1.0 and $3.0 \mathrm{mgl}^{-1} \mathrm{BAP}$ getting direct sprouting. Whilst in the present research A. titanota produced direct sprouting in the control treatment of root explants.

The usage of a liquid medium for the cultivation of cell and tissue plants improves and helps the automatization of micropropagation processes. However, the use of liquid medium induces hyperhydricity, which generates physiological problems in micro-propagated materials (Santacruz-Ruvalcaba and Portillo, 2009). 


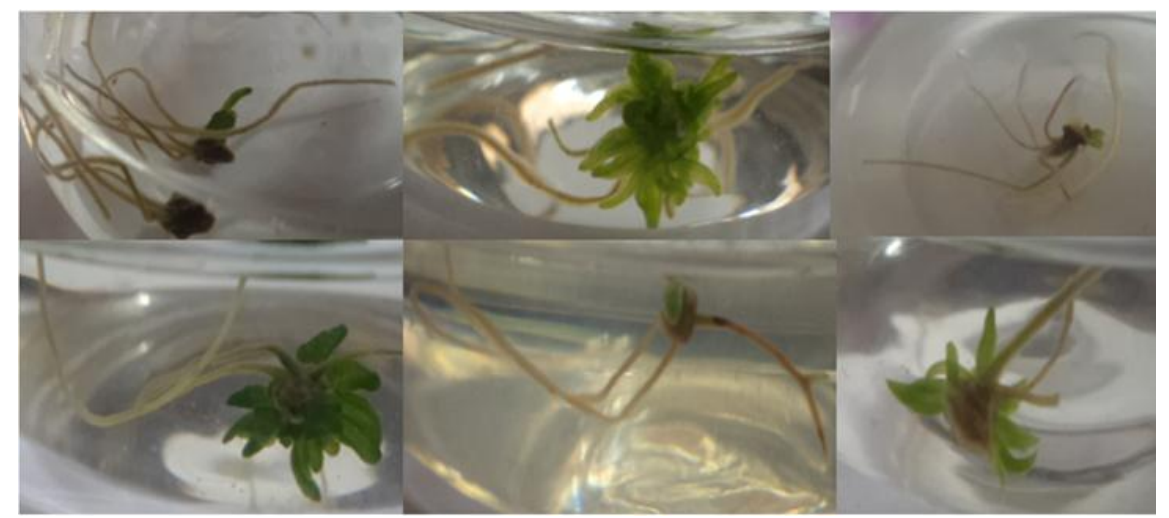

Fig 2:-Shoots of A. titanota in liquid medium free of growth regulators

It is important to mention that when the combination of BAP and 2,4-D in solid medium, the stimulation of shoots was very scarce; however, callus was obtained with $0.5 \mathrm{mgl}^{-1} \mathrm{BAP}$ plus $0.5 \mathrm{mgl}^{-1}$ 2,4-D (Figure 3). Similar case show Arzate-Fernandez and Mejia-Franco in 2011 who worked with A. angustifolia using MS 25\% supplemented with $3.0 \mathrm{mgL}^{-1}$ of 2,4-D plus $1.0 \mathrm{mgl}^{-1} \mathrm{BAP}$ in darkness and embryogenic callus was obtained. Nevertheless, in the case of this research, callus was obtained in presence of light.

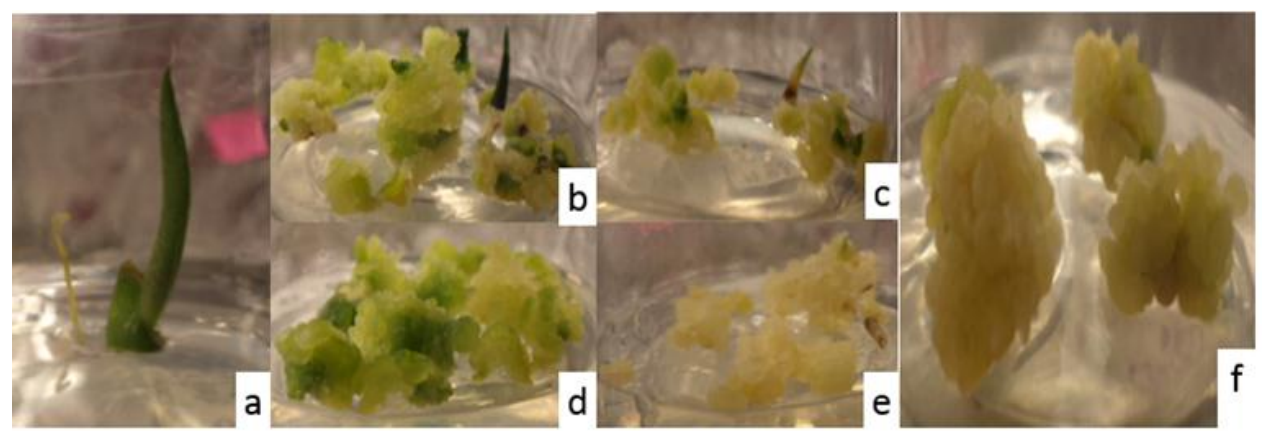

Fig 3:-Callus formation. a) basal MS, b) $0.5 \mathrm{BAP}+0.5$ 2,4-D, c) $0.5 \mathrm{BAP}+1.0$ 2,4-D, d) 0.5 BAP + 1.5 2,4-D, e) $0.5 \mathrm{BAP}+2.02,4-\mathrm{D}\left(\mathrm{mgL}^{-1}\right)$ and $\left.\mathrm{f}\right)$ Callus with globular shape embryos.

The quality in the positive response of the apex in obtaining callus with embryogenic structures in relation to other explants used is because it is a tissue with a very high percentage of meristematic cells, from which by the action of an auxin that mediates the transition from somatic cell to embryogenic cell, meristematic centers are produced these are areas of accelerated division and growth, where cells that initiate polar and asymmetric divisions are detached, thus pre-embryogenic cells are generated which become embryos (González et al., 2004).

Oxidation in the obtained material in many treatments was observed, it is possibly due to in micropropagation the exudation of phenol it is very common and frequently it affects the results (Thomas, 2008).

\section{Acknowledgements:-}

The authors thank the Master of Agricultural Sciences of the Faculty of Agricultural Sciences Campus Xalapa of the Veracruzana University and the National Council of Science and Technology (CONACYT) for their support for this research.

\section{Conclusions:-}

MS solid medium supplemented with $0.5 \mathrm{mgl}^{-1} \mathrm{NAA}$ and $1.5 \mathrm{mgl}^{-1}$ produced $60 \pm 1$ shoots by container, hydrated by the leaf. MS solid medium added with $0.5 \mathrm{mgl}^{-1} \mathrm{NAA}$ and $2.0 \mathrm{mgl}^{-1}$ BAP generates $43 \pm 1$ shoots by flask without hydration. The addition to 2,4-D and BAP to culture medium helps to embryogenic callus formation. Roots in MS liquid medium free of growth regulators are capable of producing buds. It is possible to use all of the Agave titanota seedling for shoots generation. 


\section{References:-}

1. Abreu, E., González, G., Ortíz, R., Rodríguez, P., Domech, R., Garriga, M. (2007). Aclimatación de plantas de henequén micropropagadas (Agave fourcroydes Lem.). Estudio de diferentes condiciones en la etapa de vivero. Información Técnica Económica Agraria 103 (2): 84-94.

2. Arzate-Fernández, A. M. y Mejía-Franco, R. (2011). Capacidad embriogénica de callos inducidos en ejes embrionarios cigóticos de Agave angustifolia Haw. Revista Fitotecnia Mexicana 34 (2): 101-106.

3. Aureoles-Rodríguez, F., Rodríguez-de la O, J. L., Legaria-Solano, J. P., Sahagún-Castellanos, J. y Peña-Ortega, M. G. (2008). Propagación in vitro del "maguey bruto" (Agave inaequidens Koch), una especie amenazada de interés económico. Revista Chapingo Serie Horticultura 14 (3): 263-269.

4. Binh, T. L., Muoi, L. T., Oanh, H. T. K., Thang, T. D., Phong, D. Y. (1990). Rapid propagation of agave by in vitro tissue culture. Plant Cell Tissue and Organ Culture 23: 67-70.

5. Bordallo, P. N., Silva, D. H., Maria, J., Cruz, C. D., Fontes, E. P. (2004). Somaclonal variation on in vitro callus culture potato cultivars. Horticultura Brasileira 22 (2): 300-304.

6. Castellanos-Hernández, O. A., Rodríguez-Sahagún, A., Rodríguez-Domínguez, J. M., Rodríguez-Garay, B. (2006). Organogénesis indirecta y enraizamiento in vitro de Paulownia elongata. e-Gnosis 4: 1-12.

7. Castro-Concha, L., Loyola-Vargas, V. M., Chan, J. L. y Robert, M. L. (1990). Glutamate dehydrogenase activity in normal and vitrified plants of Agave tequilana Weber propagated in vitro. Plant Cell Tissue and Organ Culture 22: 147-151.

8. Enríquez-del Valle, J. R., Estrada-Silias, A., Rodríguez-Ortíz, G., Velasco-Velasco, V. A., Campos-Ángeles, G. V. (2013). Sustrato y dosis de fertirriego en la aclimatización de vitroplantas de Agave americana var. oaxacensis. Revista de la Facultad de Ciencias Agrarias. Universidad Nacional de Cuyo 45 (2): 341-348.

9. González, G., Alemán, S., Trujillo, R., Keb, M., Abreu, E., Barredo, F., Robert, M. L., Ortiz, R., Cornides, M. T. (2004). El cultivo in vitro como alternativa de la recuperación henequenera (Agave fourcroydes). Biotecnología Aplicada 21 (1): 44-48.

10. Groenewald, E. G., Wessels, D. C. J., Koeleman, A. (1977). Callus formation and subsequent plant regeneration from seed tissue of an Agave species (Agavaceae). ZPflazenphysiol 21 (4): 369-373.

11. Madrigal-Lugo, R., Pineda-Estrada, F., Rodríguez de la O, J. L. (1989). Agave. In: Ammirato, P. V., Evans, D. A., Sharp, W. R. y Bajaj, Y. P. S. (ed.) Handbook of Plant Cell Culture, Vol. 5. Ornamental Species. McGraw Hill Publ. Co. NewYork. pp: 206-227.

12. 12.Miguel-Luna, M. E., Enríquez-del Valle, J. R., Velasco-Velasco, V. A., Villegas-Aparicio, Y., CarrilloRodríguez, J. C., Rodríguez-Ortíz, G. (2015). Composición del medio de cultivo y la incubación para enraizar brotes de Agave. Revista Mexicana de Ciencias Agrícolas Pub. Esp. (6): 1151-1159.

13. Morales-González, B., Nuñez-Palenius, H. G. (2015). Micropropagación de Agave tequilana Weber Variedad Azul "El Coronel" en un Sistema de Inmersión Temporal (SIT). Jóvenes en la Ciencia 1 (2): 77-82.

14. Murashige, T., Skoog, F. (1962). A revised medium for rapid growth and biassays with tabacco tissue cultures. Physiology Plant 15: 473-497.

15. Powers, D.E., Backhaus, R. A. (1989). In vitro propagation of Agave arizonica Gentry \& Weber. Plant Cell, Tissue and Organ Culture 16: 57-60.

16. Puente-Garza, C. A., Gutiérrez-Mora, A., García-Lara, S. (2015). Micropropagation of Agave salmiana: means to production of antioxidant and bioactive principles. Frontiers in Plant Science 6: 1-9.

17. Robert, M. L., Herrera, J. L., Contreras, F., Scorer, K. N. (1987) In vitro propagation of Agave fourcroydes Lem. (Henequen). Plant Cell Tissue and Organ Culture 8: 37-48.

18. Rodríguez-Garay, B., Gutiérrez-Mora, A., Santacruz-Ruvalcaba, F. (1996). Métodos de propagación biotecnológicos y convencionales en agaváceas para zonas áridas. In: Izquierdo, J. y Palomino, G. (es). Técnicas Convencionales y Biotecnológicas para la Propagación de Plantas de Zonas Áridas FAO Regional Office for the Latin American and Caribean Region. Santiago, Chile. pp: 57-86.

19. Sánchez-Islas, A. V., Portillo, L. (2014). Proliferación de brotes axilares en tres especies de Agave: efecto de sacarosa. Boletin Nakari 25 (3): 47-49.

20. Santacruz-Ruvalcaba, F., Portillo, L. (2009). Thin cell suspension layer as a new methodology for somatic embryogenesis in Agave tequilana Weber cultivar azul. Industrial crops and products 29: 609-614.

21. Santacruz-Ruvalcaba, F., Gutiérrez-Pulido, H., Rodríguez-Garay, B. (1999). Efficient in vitro propagation of Agave parrasana Berger. Plant Cell Tissue and Organ Culture 56: 163-167.

22. Thomas, T. D. (2008). The role of activated charcoal in plant tissue culture. Biotechnology Advances 26: 618631.

23. Zhang, Y. M., Li, X., Chen, Z., Li, J. F., Lu, J. Y., Zhou, W. Z. (2013). Shoot organogenesis and plant regeneration in Agave hybrid, No. 11648. Scientia Horticulturae 161: 30-34. 